\title{
Changes in the Components of Red Ginseng after Irradiation and the Korean Consumer's Perception of Irradiated Food
}

\author{
Yoon-Seok Choi', Jung-Min Kim', Eun-Ok Han² \\ ${ }^{1}$ Department of Bio-convergence Engineering, Korea University, Seoul, Korea; ${ }^{2}$ Department of Education and Research, Korea Academy of Nuclear Safety, \\ Seoul, Korea
}

\section{Original Research}

Received February 4, 2020

Revision March 3, 2020

Accepted March 5, 2020

Corresponding author: Eun-Ok Han

Department of Education \& Research, Korea Academy of Nuclear Safety,

260 Songpa-daero, Songpa-gu,

Seoul 05719, Korea

Tel: +82-2-554-7336

Fax: +82-2-508-7941

E-mail: haneunok@gmail.com

This is an open-access article distributed under the terms of the Creative Commons Attribution License (http://creativecommons.org/licenses/by-nc/4.0), which permits unrestricted use, distribution, and reproduction in any medium, provided the original work is properly cited.

Copyright $\odot 2020$ The Korean Association for Radiation Protection

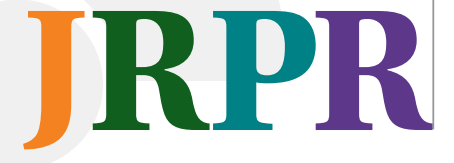

Background: We examined changes in red ginseng components after different doses of irradiation were applied. We also evaluated what housewives and teachers know about irradiated food, as well as their perceptions of and attitudes toward it.

Materials and Methods: General nutrients and unique components of irradiated ginseng were then analyzed. Education on irradiated foods and red ginseng was provided to teachers and housewives on two occasions, and changes in their behaviors were evaluated via a qualitative survey.

Results and Discussion: The ideal radiation dose to reduce the number of bacteria without changing the unique components of red ginseng is $7.5 \mathrm{kGy}$. Notably, after educational seminars on this topic, consumers' knowledge, attitudes toward, and perceptions of irradiated ginseng compared to non-irradiated red ginseng changed significantly.

Conclusion: It is necessary to provide consumers with information on irradiated foods to promote the growth of the domestic food industry, and to improve public knowledge of the safety and effects associated with the irradiation of food.

Keywords: Red Ginseng, Irradiated Food, Education, Consumer, Perception

\section{Introduction}

The oldest pharmacological work, entitled “Shinnongbonchogyeong (神農本草經)", was written about 4,500 years ago and states that ginseng is innocuous, protects the five viscera, and invigorates the body [1]. The bioactive effects of ginseng include its effects on the cardiovascular, immune, and nervous systems as well as other clinical effects, such as detoxification, antitumor activity, and antidiabetic activity [2-7]. The primary bioactive substances of ginseng include ginseng saponins (ginsenosides), polyacetylenes, acidic polysaccharides, ginseng proteins, and phenolic substances [8-10]. When fresh ginseng is steamed for 2 hours and then dried, it becomes red ginseng; the heat generated during this process produces the unique components of red ginseng, including saponin components, such as ginsenosides Rg2, Rg3, Rh1, and Rh2. The unique saponin components of red ginseng are effective for preventing cancer, inhibiting cancer cell growth, decreasing blood pressure, protecting brain cells, enhancing learning ability, and inducing antithrombotic activity and sulfation [11-24]. Based on 
these characteristics, red ginseng is a major export product and is well known among consumers as an effective natural medicine with few adverse side-effects [25].

The quality of red ginseng products is relatively uniform because these products are produced mostly by the Korea Tobacco and Ginseng Corporation. However, long-term storage or distribution of raw red ginseng materials may result in deterioration of their biological quality due to the presence of insecticides or microbes. To address this problem, chemical fumigants are typically used. Alternatively, irradiation may be used to improve the safety of storage, distribution, and consumption of red ginseng, assuming consumers accept this method of this treatment. In Korea, irradiation with $7 \mathrm{kGy}$ or less has been legally approved for the sterilization of ginseng (including red ginseng) products since 2004 [26]. The World Health Organization views the irradiation of food products as the safest and most effective food processing method and as an acceptable approach to decrease the spread of foodborne illnesses worldwide [27]. Food irradiation technology has been proven to display outstanding food sterilization, insecticide, germination inhibition, maturity regulation, and property improvement effects, since the early $20^{\text {th }}$ century, when this parasite extermination method was first patented. Later the safety of irradiated food products was officially recognized by various international organizations, including the Food and Agriculture Organization, the International Atomic Energy Agency, and the World Health Organization. After irradiation with $10 \mathrm{kGy}$ or less, the processed food products do not exhibit toxicological or biological problems [28-30]. Since the safety of irradiated food was officially recognized, irradiation of more than 250 types of foods has been approved in 52 countries. Within Korea, two gamma-radiation facilities are currently successfully operating.

Although irradiation technology has been utilized for the safe storage and distribution of foods around the globe, its utilization within the domestic sector has not grown as expected due to strict regulations regarding food irradiation programs. Additionally, consumers often have misperceptions and experience feelings of anxiety with regard to irradiated food. Thus, to change the general misperceptions surrounding irradiated foods, it is necessary to develop existing and additional policies and conduct more studies of all food products [31]. Without accurate information on irradiated foods, consumers are uncertain about the safety of these foods and may be reluctant to purchase such foods [32]. Consumers' acceptability of irradiated foods is relatively low, mainly because of concerns regarding general safety [33]. However, regardless of how scientifically outstanding, economical, and safe a technology may be, the distribution and utilization of irradiated food products faces challenges which the general public does not appear to willingly accept [34]. Thus, various approaches must be applied in order to improve consumers' understanding of food irradiation.

Therefore, in this study, the researchers have aimed to analyze changes in red ginseng components after the irradiation process according to legally approved radiation dosages, in order to provide an objective analysis of component changes in the experimental samples. In addition, a survey was conducted among housewives, who are major consumers of red ginseng, and teachers, who are viewed as having a high level of scientific understanding on this topic, in order to observe changes in their knowledge and perceptions of irradiated red ginseng and their subsequent attitudes toward this irradiated product. This study was designed to evaluate whether irradiated foods could be accepted and adopted favorably by the general public following sufficient educational awareness on this topic.

\section{Materials and Methods}

\section{Study Design}

Red ginseng powder samples (6-year-old, Punggi Ginseng products of high preference among consumers; verified by the Korea Tobacco and Ginseng Corporation) were purchased. The expiration date of these products was April 25, 2019. Red ginseng powder was then irradiated at five doses $(0,2.5,5,7.5,10 \mathrm{kGy})$ to produce red ginseng powder using the ${ }^{60} \mathrm{Co}$ gamma radiation facility at Greenpia Technology Inc., Yeoju, Korea. The components of the red ginseng powder were then analyzed based on the radiation dosage after storage at room temperature. The powder was visually inspected and analyzed considering the following factors: heat quantity, carbohydrates, crude proteins, crude fats, sodium, sugars, saturated fatty acids, trans fats, cholesterol, and bacterial numbers. To ensure a high level of reliability, the Korea Advanced Food Research Institute performed the major component analysis. The 10 components analyzed in this study are included on the labels of most food products. The unique components and characteristics of red ginseng (stored at room temperature) were analyzed as follows: ginsenosides Rg1, Rb1, and Rg3; saponins; humidity; particle size; foreign substances; lead; cadmium; tin; bacterial num- 
bers; and coliform bacteria. This analysis was also performed by the Korea Ginseng Product Corporation.

Educational seminars were conducted on irradiated foods and red ginseng on two occasions for teachers, who are considered to be highly educated, and housewives, who are evidently the major consumers of red ginseng. Educational content included the principles, legal basis, and history of irradiated foods; nutrients and components of red ginseng; advantages and disadvantages of the irradiation process; and changes in the experimental food components depending upon the irradiation dosage. To examine changes in consumers' knowledge, perceptions, and attitudes toward irradiated red ginseng following educational seminars, a survey and statistical analysis were conducted. Additionally, changes in consumers' behaviors following educational awareness were observed.

\section{Participants}

A survey was conducted among 70 individuals, including 20 men $(28.6 \%)$ and 50 women (71.4\%), and changes in their behaviors were observed thereafter. Between July and November 2017, four educational seminars were provided for the participants in addition to a survey, and observations of participant behavioral changes were documented. The participants included 37 teachers (46.8\%) and 42 housewives (53.1\%). For $85 \%$ of participants, their monthly incomes ranged from 2 million to 8 million Korean won. Questionnaire items included their intake and purchasing of ordinary red ginseng and irradiated red ginseng, consumption patterns, knowledge of red ginseng effects and safety, and general attitudes.

As part of the educational process, data regarding changes in red ginseng components depending on radiation dose were presented. The participants were then asked to choose from red ginseng samples exposed to 0-10 kGy irradiation, and then informed to consume the samples provided. In this experiment, participants who consumed irradiated red ginseng were given 1 point for each step; 2 points were considered as a perfect score for this experiment.

\section{Statistical Analysis}

SPSS version 15.0 for Windows (SPSS Inc., Chicago, IL, USA) was used to analyze the data. Data are presented as frequencies and percentages or means and standard deviations. Statistical analyses were carried out using Pearson correlation coefficients, $t$-tests, and multiple regression.

\section{Results and Discussion}

\section{Changes in Unique Components of Red Ginseng Powder following Irradiation}

Firstly, analyzed changes in the unique components of red ginseng powder after irradiation were documented. Notably, there were no significant changes in the major components of red ginseng, regardless of the radiation dosage. In contrast, bacterial numbers decreased dramatically as the radiation

Table 1. Changes in Unique Components of Red Ginseng Powder following Irradiation

\begin{tabular}{|c|c|c|c|c|c|}
\hline \multirow{2}{*}{ Classification } & \multicolumn{5}{|c|}{ Irradiation } \\
\hline & 0 kGy & 2.5 kGy & 5 kGy & 7.5 kGy & 10 kGy \\
\hline Sum of ginsenosides Rg1, Rb1, and Rg3 (mg/g) & 6.94 & 6.14 & 7.38 & 6.58 & 6.5 \\
\hline Ginsenoside Rg1 (mg/g) & 2.53 & 2.18 & 2.61 & 2.44 & 2.26 \\
\hline Ginsenoside Rb1 (mg/g) & 4.16 & 3.74 & 4.55 & 3.94 & 4.05 \\
\hline Ginsenoside Rg3 (mg/g) & 0.25 & 0.22 & 0.22 & 0.21 & 0.2 \\
\hline Saponin (mg/g) & 75.4 & 76.4 & 74.8 & 70.3 & 75.9 \\
\hline Red ginseng components & Detected & Detected & Detected & Detected & Detected \\
\hline Moisture (\%) & 2.9 & 2.7 & 2 & 2.7 & 2.3 \\
\hline Particle size (\%) & 74.8 & 79.3 & 80 & 79.9 & 75.9 \\
\hline Foreign substance & None & None & None & None & None \\
\hline Lead (mg/kg) & 0.2 & 0.2 & 0.2 & 0.2 & 0.4 \\
\hline Cadmium (mg/kg) & 0.1 & 0.1 & 0.1 & 0.1 & 0.1 \\
\hline Tin $(\mathrm{mg} / \mathrm{kg})$ & 9 & 12.4 & 13.6 & 9.5 & 11.3 \\
\hline Bacterial number* (CFU/g) & 14,000 & 65 & 45 & 0 & 10 \\
\hline Coliform bacteria & Negative & Negative & Negative & Negative & Negative \\
\hline
\end{tabular}

Unique components of red ginseng are the major components of ginseng suggested by the Korea Ginseng Product Corporation.

*In microbiology, colony-forming units (CFUs) are a measure of the number of visible bacteria or fungi. Unlike counting all living or dying cells directly under a microscope, measuring CFU is measuring visible cells. In solids it is given in CFU/g (colonized units per gram). 
dosage increased. Without irradiation, the number of bacteria was quite high; however, after irradiation at the legally approved dose of $7.5 \mathrm{kGy}$, the number of bacteria was significantly reduced, without changes in the unique components of ginseng (Table 1).

\section{Changes in the General Nutrient Components of Red Ginseng Powder following Irradiation at Different Doses}

Upon visual inspection, the yellowish brown powder of irradiated ginseng maintained a constant level of chromaticity, regardless of the irradiation dose. Nine components showed no significant differences following irradiation. In contrast, changes in bacterial contents were observed after irradiation with doses of more than $2.5 \mathrm{kGy}$ (Table 2).

\section{Changes in Participants' Knowledge, Perceptions, and Attitudes towards Irradiated Red Ginseng following Educational Awareness}

Following educational awareness, there were no signifi- cant changes in the participants' perception regarding the safety of non-irradiated red ginseng. However, in relation to

Table 2. Changes in the General Nutrient Components of Red Ginseng Powder following Irradiation at Different Doses

\begin{tabular}{lccccc}
\hline \multirow{2}{*}{ Classification } & \multicolumn{5}{c}{ Irradiation } \\
\cline { 2 - 6 } & 0 kGy & 2.5 kGy & 5 kGy & 7.5 kGy & 10 kGy \\
\hline Calories (per 100 g) & 374.1 & 373.6 & 374.3 & 372.8 & 371.9 \\
Carbohydrates & 77.4 & 77.5 & 77.7 & 77.3 & 77.1 \\
$\begin{array}{l}\text { Crude protein } \\
\quad \text { (nitrogen factor =6.25) }\end{array}$ & 13.2 & 13.2 & 13.4 & 13.2 & 13.4 \\
Crude fat & 1.3 & 1.2 & 1.1 & 1.2 & 1.1 \\
Sodium & 73.01 & 63.42 & 70.18 & 66.18 & 62.51 \\
Sugars & 20.3 & 20.3 & 20.4 & 20.3 & 20.2 \\
Saturated fatty acids & 0.2 & 0.2 & 0.2 & 0.2 & 0.2 \\
Trans fats & 0.01 & 0.01 & 0.01 & 0.01 & 0.01 \\
Cholesterol & Not & Not & Not & Not & Not \\
& detected detected detected detected detected \\
Bacterial number (/g) & 570 & 20 & 0 & 0 & 0 \\
\hline
\end{tabular}

General nutrient components of red ginseng powder are the major nutrient components of all types of foods for consumers suggested by the Korea Advanced Food Research Institute. There is no absolute standard for the normal range of each measurement.

Table 3. Changes in Participants' Knowledge, Perceptions, and Attitudes towards Irradiated Red Ginseng following Educational Awareness

\begin{tabular}{|c|c|c|c|c|c|c|c|}
\hline \multirow[t]{2}{*}{ Classification } & \multirow[t]{2}{*}{ Education } & \multicolumn{2}{|c|}{$\begin{array}{l}\text { Knowledge of irradiated } \\
\text { red ginseng }\end{array}$} & \multicolumn{2}{|c|}{$\begin{array}{l}\text { Perception of ordinary } \\
\text { red ginseng safety }\end{array}$} & \multicolumn{2}{|c|}{$\begin{array}{l}\text { Perception of irradiated } \\
\text { red ginseng safety }\end{array}$} \\
\hline & & Score & $t(p$-value) & Score & $t$ (p-value) & Score & $t(p$-value) \\
\hline \multicolumn{8}{|l|}{ Sex } \\
\hline Male & $\begin{array}{l}\text { Before } \\
\text { After }\end{array}$ & $\begin{array}{l}2.26 \pm 1.88 \\
4.37 \pm 1.16\end{array}$ & $-4.800(0.000)^{\star \star}$ & $\begin{array}{l}3.95 \pm 0.76 \\
4.15 \pm 0.75\end{array}$ & $-1.165(0.258)$ & $\begin{array}{l}3.40 \pm 0.99 \\
4.10 \pm 0.64\end{array}$ & $-4.273(0.000)^{\star \star}$ \\
\hline Female & $\begin{array}{l}\text { Before } \\
\text { After }\end{array}$ & $\begin{array}{l}1.27 \pm 1.48 \\
3.29 \pm 1.60\end{array}$ & $-8.782(0.000)^{\star \star}$ & $\begin{array}{l}3.79 \pm 0.74 \\
3.69 \pm 0.88\end{array}$ & $0.819(0.417)$ & $\begin{array}{l}3.32 \pm 0.78 \\
3.83 \pm 0.73\end{array}$ & $-3.675(0.001)^{\star \star}$ \\
\hline \multicolumn{8}{|l|}{ Occupation } \\
\hline Teacher & $\begin{array}{l}\text { Before } \\
\text { After }\end{array}$ & $\begin{array}{l}2.18 \pm 1.72 \\
4.36 \pm 1.03\end{array}$ & $-7.694(0.000)^{\star \star}$ & $\begin{array}{l}3.91 \pm 0.71 \\
4.12 \pm 0.69\end{array}$ & $-1.559(0.128)$ & $\begin{array}{l}3.29 \pm 0.87 \\
4.00 \pm 0.60\end{array}$ & $-5.725(0.000)^{\star \star}$ \\
\hline Housewife & $\begin{array}{l}\text { Before } \\
\text { After }\end{array}$ & $\begin{array}{l}0.90 \pm 1.33 \\
2.81 \pm 1.64\end{array}$ & $-6.306(0.000)^{\star \star}$ & $\begin{array}{l}3.76 \pm 0.78 \\
3.53 \pm 0.93\end{array}$ & $1.542(0.133)$ & $\begin{array}{l}3.39 \pm 0.83 \\
3.82 \pm 0.81\end{array}$ & $-2.362(0.024)^{*}$ \\
\hline \multicolumn{8}{|l|}{ Married } \\
\hline Single & $\begin{array}{l}\text { Before } \\
\text { After }\end{array}$ & $\begin{array}{l}1.80 \pm 1.30 \\
4.00 \pm 1.22\end{array}$ & $-5.880(0.004)^{\star}$ & $\begin{array}{l}3.83 \pm 0.75 \\
4.17 \pm 0.41\end{array}$ & $-1.581(0.175)$ & $\begin{array}{l}3.50 \pm 0.55 \\
4.17 \pm 0.41\end{array}$ & $-2.000(0.102)$ \\
\hline Married & $\begin{array}{l}\text { Before } \\
\text { After }\end{array}$ & $\begin{array}{l}1.47 \pm 1.66 \\
3.53 \pm 1.59\end{array}$ & $-9.088(0.000)^{\star \star}$ & $\begin{array}{l}3.83 \pm 0.74 \\
3.75 \pm 0.88\end{array}$ & $0.760(0.450)$ & $\begin{array}{l}3.29 \pm 0.85 \\
3.86 \pm 0.73\end{array}$ & $-4.845(0.000)^{\star \star}$ \\
\hline \multicolumn{8}{|c|}{ Ordinary red ginseng intake experience } \\
\hline Yes & $\begin{array}{l}\text { Before } \\
\text { After }\end{array}$ & $\begin{array}{l}1.51 \pm 1.62 \\
3.56 \pm 1.58\end{array}$ & $-9.715(0.000)^{\star \star}$ & $\begin{array}{l}3.82 \pm 0.75 \\
3.78 \pm 0.86\end{array}$ & $0.287(0.775)$ & $\begin{array}{l}3.30 \pm 0.83 \\
3.88 \pm 0.70\end{array}$ & $-5.110(0.000)^{\star \star}$ \\
\hline No & $\begin{array}{l}\text { Before } \\
\text { After }\end{array}$ & $\begin{array}{l}2.67 \pm 2.52 \\
4.67 \pm 0.58\end{array}$ & $-1.732(0.225)$ & $\begin{array}{l}4.33 \pm 0.58 \\
4.67 \pm 0.58\end{array}$ & $-1.000(0.423)$ & $\begin{array}{l}4.33 \pm 0.58 \\
4.67 \pm 0.58\end{array}$ & $-1.000(0.423)$ \\
\hline \multicolumn{8}{|c|}{ Irradiated red ginseng intake experience } \\
\hline Yes & $\begin{array}{l}\text { Before } \\
\text { After }\end{array}$ & $\begin{array}{l}4.00 \pm 1.41 \\
4.40 \pm 0.89\end{array}$ & $-1.000(0.374)$ & $\begin{array}{l}4.20 \pm 0.84 \\
4.20 \pm 0.84\end{array}$ & $0.000(1.000)$ & $\begin{array}{l}3.60 \pm 1.52 \\
4.20 \pm 0.84\end{array}$ & $-1.500(0.208)$ \\
\hline No & $\begin{array}{l}\text { Before } \\
\text { After }\end{array}$ & $\begin{array}{l}1.36 \pm 1.52 \\
3.54 \pm 1.59\end{array}$ & $-10.342(0.000)^{\star *}$ & $\begin{array}{l}3.81 \pm 0.74 \\
3.79 \pm 0.86\end{array}$ & $0.145(0.885)$ & $\begin{array}{l}3.32 \pm 0.78 \\
3.89 \pm 0.70\end{array}$ & $-4.947(0.000)^{\star \star}$ \\
\hline
\end{tabular}

Values are presented as mean \pm standard deviation.

The questionnaire included five knowledge-related questions; 5 points was considered a perfect score.

${ }^{*} p<0.05,{ }^{* *} p<0.01$. 
irradiated red ginseng, participants' knowledge and perceptions of food safety measures improved after education depending on sex, occupation, marital status, and whether participants had experience with the consumption of nonirradiated or irradiated red ginseng. Thus, this study suggests that participants who previously had little knowledge of irradiation showed significant changes in their knowledge and perception after educational awareness on the topic of the irradiation of food products (Table 3 ).

\section{Changes in the Participants' Attitudes towards Choosing Red Ginseng Products after Educational Seminars}

Regarding non-irradiated red ginseng, there were no significant changes in participants' attitudes towards choosing red ginseng products after education, although the number of individuals stating that they would choose ordinary red ginseng increased after educational awareness. In contrast, for irradiated red ginseng, the participants' perception of safety improved after education on the topic depending on sex, occupation, marriage status, and whether they had experience with the intake of non-irradiated red ginseng or irradiated red ginseng. Thus, participants who had inadequate knowledge of the effects of irradiation prior to educational seminars, showed significant changes in their attitudes towards irradiated red ginseng following educational awareness (Table 4).

\section{Correlations among the Perceptions, Knowledge, and Attitudes toward Red Ginseng}

Following educational seminars, attitudes towards choosing both non-irradiates and irradiated red ginseng were correlated with a perception of safety of $(\rho=0.387, \rho=0.462)$, a perception of necessity of $(\rho=0.483, \rho=0.530)$, and knowledge variable of $(\rho=0.303, \rho=0.245)$. The level of correlation was statistically significant. Among these factors, attitudes

Table 4. Changes in the Participants' Attitudes towards Choosing Red Ginseng Products after Educational Seminars

\begin{tabular}{|c|c|c|c|c|c|}
\hline \multirow{2}{*}{ Classification } & \multirow{2}{*}{ Education } & \multicolumn{2}{|c|}{ Attitudes towards ordinary red ginseng } & \multicolumn{2}{|c|}{ Attitudes toward irradiated red ginseng } \\
\hline & & Score & $t(p$-value) & Score & $t(p$-value) \\
\hline \multicolumn{6}{|l|}{ Sex } \\
\hline \multirow[t]{2}{*}{ Male } & Before & $1.70 \pm 0.73$ & $1.453(0.163)$ & $0.84 \pm 1.01$ & $-1.756(0.096)$ \\
\hline & After & $1.50 \pm 0.89$ & & $1.37 \pm 0.96$ & \\
\hline \multirow[t]{2}{*}{ Female } & Before & $1.20 \pm 0.97$ & $-1.124(0.267)$ & $0.34 \pm 0.76$ & $-5.152(0.000)^{\star \star}$ \\
\hline & After & $1.36 \pm 0.93$ & & $1.29 \pm 0.96$ & \\
\hline \multicolumn{6}{|l|}{ Occupation } \\
\hline \multirow[t]{2}{*}{ Teacher } & Before & $1.64 \pm 0.78$ & $0.000(1.000)$ & $0.65 \pm 0.95$ & $-3.230(0.003)^{*}$ \\
\hline & After & $1.64 \pm 0.78$ & & $1.42 \pm 0.92$ & \\
\hline \multirow[t]{2}{*}{ Housewife } & Before & $1.06 \pm 0.98$ & $-0.533(0.598)$ & $0.34 \pm 0.77$ & $-4.126(0.000)^{\star \star}$ \\
\hline & After & $1.16 \pm 0.99$ & & $1.21 \pm 0.98$ & \\
\hline \multicolumn{6}{|l|}{ Married } \\
\hline \multirow[t]{2}{*}{ Single } & Before & $0.34 \pm 0.77$ & $-4.126(0.000)^{\star \star}$ & $0.67 \pm 1.03$ & $-0.542(0.611)$ \\
\hline & After & $1.21 \pm 0.98$ & & $1.00 \pm 1.10$ & \\
\hline \multirow[t]{2}{*}{ Married } & Before & $1.33 \pm 0.93$ & $-0.477(0.635)$ & $0.50 \pm 0.87$ & $-4.969(0.000)^{\star \star}$ \\
\hline & After & $1.39 \pm 0.92$ & & $1.33 \pm 0.94$ & \\
\hline \multicolumn{6}{|c|}{ Ordinary red ginseng intake experience } \\
\hline \multirow[t]{2}{*}{ Yes } & Before & $1.35 \pm 0.93$ & $-0.435(0.665)$ & $0.42 \pm 0.82$ & $-5.674(0.000)^{\star \star}$ \\
\hline & After & $1.40 \pm 0.91$ & & $1.32 \pm 0.95$ & \\
\hline \multirow[t]{2}{*}{ No } & Before & $1.33 \pm 1.15$ & - & $2.00 \pm 0.00$ & $1.000(0.423)$ \\
\hline & After & $1.33 \pm 1.15$ & & $1.33 \pm 1.15$ & \\
\hline \multicolumn{6}{|c|}{ Irradiated red ginseng intake experience } \\
\hline \multirow[t]{2}{*}{ Yes } & Before & $1.60 \pm 0.89$ & - & $1.20 \pm 1.10$ & $-1.000(0.374)$ \\
\hline & After & $1.60 \pm 0.89$ & & $1.60 \pm 0.89$ & \\
\hline \multirow[t]{2}{*}{ No } & Before & $1.33 \pm 0.93$ & $-0.435(0.665)$ & $0.44 \pm 0.83$ & $-5.056(0.000)^{\star \star}$ \\
\hline & After & $1.38 \pm 0.92$ & & $1.29 \pm 0.96$ & \\
\hline
\end{tabular}

Values are presented as mean \pm standard deviation.

Attitudes toward choosing red ginseng were measured based on the sum of participants' attitudes toward choosing ordinary or irradiated red ginseng. A high score indicated that the participant was more likely to choose red ginseng.

${ }^{*} p<0.05,{ }^{* *} p<0.01$. 
towards choosing non-irradiated red ginseng and irradiated red ginseng were highly correlated with the perception of necessity, and the perception of necessity for both non-irradiated and irradiated red ginseng were highly correlated with the perception of safety $(\rho=0.917, \rho=0.844)$. Thus, when individuals were aware of the necessity of buying irradiated red ginseng, they were likely to choose irradiated red ginseng and were more likely to be concerned about food product safety (Table 5).

\section{Factors Affecting Attitudes towards Red Ginseng}

In multiple linear regression analysis, attitudes towards choosing non-irradiated and irradiated red ginseng after education were the dependent variable, and perception of safety, perception of necessity, and knowledge, were the independent variables. The results showed significant differences before and after education. In particular, the perception of necessity of both non-irradiated and irradiated red ginseng significantly affected attitudes towards choosing red ginseng following education on the topic. In other words, those who were aware of the necessity of red ginseng were likely to purchase either non-irradiated or irradiated red ginseng, indi- cating that education on this topic influenced consumers' tendencies to choose irradiated red ginseng (Table 6).

\section{Conclusion}

Food irradiation technology has been developed through various studies conducted by developed countries and has been shown to be more effective than any other sanitation treatment to improve food product safety in terms of microbiology, toxicology, dietetics, and genetics. However, the use of irradiated foods in Korea still remains low, potentially because of the low level of understanding and acceptability of irradiated foods among consumers and food producers [35]. To promote a safe domestic food industry and to improve general public health, it is necessary to provide consumers with information on irradiated foods to facilitate decision making. Due to the fact that negative views regarding nuclear energy and irradiation are prevalent, it is necessary to provide accurate information on the use of nuclear energy usages and irradiated foods. Accordingly, in this study, we evaluated the components of red ginseng and then assessed changes in consumers' knowledge and attitudes towards red

Table 5. Correlations among the Perceptions, Knowledge, and Attitudes toward Red Ginseng

\begin{tabular}{|c|c|c|c|c|c|c|c|c|}
\hline \multirow[b]{2}{*}{ Classification } & \multicolumn{4}{|c|}{ Ordinary red ginseng intake } & \multicolumn{4}{|c|}{ Irradiated red ginseng safety } \\
\hline & $\begin{array}{l}\text { Attitudes toward } \\
\text { choosing } \\
\text { red ginseng }\end{array}$ & $\begin{array}{c}\text { Safety } \\
\text { perception }\end{array}$ & $\begin{array}{l}\text { Necessity } \\
\text { perception }\end{array}$ & Knowledge & $\begin{array}{l}\text { Attitudes toward } \\
\text { choosing } \\
\text { red ginseng }\end{array}$ & $\begin{array}{c}\text { Safety } \\
\text { perception }\end{array}$ & $\begin{array}{l}\text { Necessity } \\
\text { perception }\end{array}$ & Knowledge \\
\hline Attitudes toward choosing red ginseng & 1 & & & & 1 & & & \\
\hline Safety perception & $0.387^{\star *}$ & 1 & & & $0.462^{\star \star}$ & 1 & & \\
\hline Necessity perception & $0.483^{\star *}$ & $0.917^{\star \star}$ & 1 & & $0.530^{\star \star}$ & $0.844^{\star \star}$ & 1 & \\
\hline Knowledge & $0.303^{*}$ & $0.497^{\star \star}$ & $0.450^{\star \star}$ & 1 & $0.245^{\star}$ & $0.517^{\star \star}$ & $0.493^{\star *}$ & 1 \\
\hline
\end{tabular}

${ }^{*} p<0.05,{ }^{* *} p<0.01$.

Table 6. Factors Affecting Attitudes towards Red Ginseng

\begin{tabular}{|c|c|c|c|c|c|}
\hline \multirow{2}{*}{ Classification } & \multirow{2}{*}{ Item } & \multicolumn{2}{|c|}{ Unstandardized coefficient } & \multirow{2}{*}{$\frac{\text { Standardized coefficient }}{\text { Beta }}$} & \multirow{2}{*}{$t$} \\
\hline & & B & Standard error & & \\
\hline \multirow[t]{5}{*}{ Ordinary red ginseng } & (constant) & -0.642 & 0.473 & & -1.358 \\
\hline & Perception of safety & -0.357 & 0.285 & -0.347 & -1.252 \\
\hline & Perception of necessity & 0.840 & 0.308 & 0.735 & $2.732^{\star *}$ \\
\hline & Knowledge & 0.083 & 0.071 & 0.144 & 1.165 \\
\hline & & & $F=7.486^{\star \star}, R^{2}=0.260$ & & \\
\hline \multirow[t]{5}{*}{ Irradiated red ginseng } & (constant) & -1.364 & 0.570 & & -2.392 \\
\hline & Perception of safety & 0.079 & 0.263 & 0.061 & 0.302 \\
\hline & Perception of necessity & 0.680 & 0.274 & 0.493 & $2.481^{*}$ \\
\hline & Knowledge & -0.018 & 0.075 & -0.030 & -0.241 \\
\hline & & & $F=8.404^{\star \star}, R^{2}=0.283$ & & \\
\hline
\end{tabular}

${ }^{*} p<0.05,{ }^{* *} p<0.01$ 
ginseng.

The major saponin components of fresh ginseng and white ginseng are $\mathrm{Rb} 1, \mathrm{Rb} 2, \mathrm{Re}$, and $\mathrm{Rg} 1[36,37]$. During the thermal treatment of red ginseng, new unique saponin components of red ginseng, including ginsenosides Rg2, Rg3, Rh1, and Rh2, were produced. These saponin elements are known to have effects in preventing cancer, inhibiting cancer cell growth, protecting brain cells, enhancing learning ability, and inducing antioxidant activity [11, 17, 20, 21, 23]. Rg3 is generated upon $\mathrm{Rbl}$ hydrolysis. This is a unique compound that exists only in red ginseng, and the quantity of this element increases in high-temperature steaming conditions $[11,17,20,38]$. Our results showed that there were no changes in the levels of these compounds following irradiation, suggesting that irradiated red ginseng maintained its efficacy. Several studies have demonstrated that food irradiation yields safe food products by extending the effective storage period and deactivating germs [39]. Moreover, irradiation has not been shown to affect nutrients in comparison with other technologies used for food processing and preservation. Major nutrients, such as proteins, carbohydrates, and fats, are stable up to an irradiation level of $10 \mathrm{kGy}$ [40]. The patterns observed in this study were consistent with those observed in previous studies.

Many respondents are concerned that irradiated food products may become radioactive following treatments, and essentially the central purpose and benefits of food irradiation may be ignored. Consumers may believe that irradiation may change the organic qualities of the product, such as flavor and smell, and cause a significant loss of nutrients [41]. It has been noted that such negative perceptions have persisted for more than 10 years in Korea. This is a serious problem that must be overcome through the development of advanced educational programs [42]. In this study, the participants showed significant changes in their knowledge, perception, and attitudes after being educated on the changes in components of irradiated red ginseng. This indicates that even consumers who lack knowledge of the irradiation process, or have negative views on irradiation, may change their attitudes and accept irradiated foods as they learn more about irradiation methods and the advantages of irradiation. Hence, education is of great importance to general acceptability of irradiated foods [33], and it is necessary to provide consumers with more information on irradiated foods and future educational opportunities. As reported previously [43], differences in perceptions surrounding the level of risk among everyday consumer's results not from the mistaken recognition of statistical data regarding risks, but from the different levels of exposure to vernacular related to risk factors experienced by individuals and their meanings in a typical living environment [43]. People often face situations in which they have to choose among various behaviors in daily life. They are likely to make decisions after considering the benefits and disadvantages of each behavior [44]. This is why science educators and researchers emphasize the importance of developing the ability to judge values and make decisions rationally based on an accurate understanding of scientific technologies [45-48]. Accordingly, it is necessary to provide accurate information on red ginseng and other foods for which irradiation is permitted, in order to familiarize consumers with the benefits associated with irradiated foods. Furthermore, experts must develop strategies to help consumers make informed decisions and increase their acceptability of such food products.

\section{Conflict of Interest}

No potential conflict of interest relevant to this article was reported.

\section{Acknowledgements}

This work was supported by the Promotion of Radiation Safety Culture Project coordinated by the Nuclear Safety Research and Development of Nuclear Safety \& Security Commission.

\section{References}

1. Namba T. The encyclopedia of Wakan-Yaku with color pictures I. Osaka, Japan: Hoikusha; 1980.

2. Lee DC, Lee MO, Kim CY, Clifford DH. Effect of ether, ethanol and aqueous extracts of ginseng on cardiovascular function in dogs. Can J Comp Med. 1981;45:182-187.

3. Jie YH, Cammisuli S, Baggiolini M. Immunomodulatory effects of Panax Ginseng C.A. Meyer in the mouse. Agents Actions. 1984; 15:386-391

4. Kim YC, Kim SR, Markelonis GJ, Oh TH. Ginsenosides Rb1 and Rg3 protect cultured rat cortical cells from glutamate-induced neurodegeneration. J Neurosci Res. 1998;53:426-432.

5. Joo CN, Koo JD, Kim DS, Lee SJ. Biochemical studies of ginseng saponins. XI. The effects of ginseng saponins on alcohol dehydrogenase. Hanguk Saenghwa Hakhoe Chi. 1977:10:109-120. 
6. Tahara M, Kono H, Mune S, Odashima S. Action of ginsenosides on tumor cells: growth inhibition and redifferentiation of neoplasia. Wakan Yaku Gakkaishi. 1985;2:170-171.

7. Yokozawa T, Kobayashi T, Oura H, Kawashima Y. Studies on the mechanism of the hypoglycemic activity of ginsenoside-Rb2 in streptozotocin-diabetic rats. Chem Pharm Bull. 1985;33:869-872.

8. Park JD. Recent studies on the chemical constituents of Korean ginseng (Panax ginseng CA Meyer). Korean J Ginseng Sci. 1996; 20:389-415.

9. Shibata S, Sanata S, Kondo N, Shoji J, Tanaka O. Studies on the saponins of ginseng. I. Structure of ginseng-R0, Rb1, Rb2, RC and Rd. Chem Pharm Bull. 1974;22:421-428.

10. Kitagawa I, Taniyama T, Shibuya H, Noda T, Yoshikawa M. Chemical studies on crude drug processing. V. On the constituents of ginseng radix rubra (2): Comparison of the constituents of white ginseng and red ginseng prepared from the same Panax ginseng root. Yakugaku Zasshi. 1987;107:495-505.

11. Keum YS, Park KK, Lee JM, Chun KS, Park JH, Lee SK, et al. Antioxidant and anti-tumor promoting activities of the methanol extract of heat-processed ginseng. Cancer Lett. 2000;150:41-48.

12. Kim SE, Lee YH, Park JH, Lee SK. Ginsenoside-Rs3, a new dioltype ginseng saponin, selectively elevates protein levels of p53 and p21WAF1 leading to induction of apoptosis in SK-HEP-1 cells. Anticancer Res. 1999;19:487-91.

13. Kim WY, Kim JM, Han SB, Lee SK, Kim ND, Park MK, et al. Steaming of ginseng at high temperature enhances biological activity. J Nat Prod. 2000;63:1702-1704.

14. Bao HY, Zhang J, Yeo SJ, Myung CS, Kim HM, Kim JM, et al. Memory enhancing and neuroprotective effects of selected ginsenosides. Arch Pharm Res. 2005;28:335-342.

15. Jung KY, Kim DS, Oh SR, Lee IS, Lee JJ, Park JD, et al. Platelet activating factor antagonist activity of ginsenosides. Biol Pharm Bull. 1998;21:79-80.

16. Jo HK, Sung MC, Ko SK. The comparison of ginseng prosapogenin composition and contents in Red and Black ginseng. Korean J Pharmacogn. 2011;42:361-365.

17. Yun TK, Lee YS, Lee YH, Yun HY. Cancer chemopreventive compounds of red ginseng produced from Panax ginseng CA Meyer. J Ginseng Res. 2001;25:107-111.

18. Jeon BH, Kim HS, Chang SJ. Effect of saponin and non-saponin of Panax ginseng on the blood pressure in the renovascular hypertensive rats. J Ginseng Res. 1999;23:81-87.

19. Kang SY, Kim ND. The antihypertensive effect of red ginseng saponin and the endothelium-derived vascular relaxation. Korean J Ginseng Sci. 1992;16:175-182.

20. Kim DH, Kwak KH, Lee KJ, Kim SJ, Shin YC, Chun BG, et al. Effects of Korea red ginseng total saponin on repeated unpredictable stress-induced changes of proliferation of neural progenitor cells and BDNF mRNA expression in adult rat hippocampus. J Ginseng Res. 2004;28:94-103.
21. Petkov VD, Mosharrof AH. Effects of standardized ginseng extract on learning, memory and physical capabilities. Am J Chin Med. 1987;15:19-29.

22. Lee JH, Park HJ. Effects of lipophilic fraction from Korean red ginseng on platelet aggregation and blood coagulation in rats fed with corn oil and beeftallow diet. Korean J Ginseng Sci. 1995; 3:206-211.

23. Bae KC, Kim SH. Antioxidant effects of Korea ginseng radix, Korea red ginseng radix and total saponin. Korean J Orient Med Pathol. 1998;12:72-81.

24. Jeon YE, Kim JK, Yin XF, Lee JW, Nam JS, Kang IJ. Oral toxicity study on the 90-day repeated-dose of $50 \mathrm{kGy}$ irradiated methanol extract powder of red ginseng. J Korean Soc Food Sci Nutr. 2011;40:824-831.

25. Yeo G, Park JY, Cho MS. The perception and preference of redginseng and green tea Yackwa among Korean, Chinese, Japanese female consumer. J East Asian Soc Diet Life. 2013;23:533-545.

26. Korea Food and Drug Administration. Food Standards \& Specifications. Seoul, Korea: Food and Drug Administration; 2012.

27. Kim YM. The position of WHO on food irradiation. J Food Hyg Saf. 1994;9:S13-S16.

28. World Health Organization. Wholesomeness of irradiated food: report of a Joint FAO/IAEA/WHO Expert Committee [Internet]. Geneva, Switzerland; World Health Organization; 1981 [cited 2020 Mar 1]. Available from: https://apps.who.int/iris/handle/ $10665 / 41508$.

29. World Health Organization. Food irradiation: a technique for preserving and improving the safety of food. Geneva, Switzerland: World Health Organization; 1988.

30. General Standard for Irradiated Foods (CODEX STAN 106-1983, REV.1-2003) [Internet]. Rome, Italy: Food and Agriculture Organization of the United Nations; 2008 [cited 2020 Mar 1]. Available from: http://www.fao.org/input/download/standards/16/ CXS_106e.pdf.

31. Yoon HS, Park S, Sung R, Chang Y, Cho T, Kang M, et al. Studies on detection method of irradiated foods. Seoul, Korea: Korea Food \& Drug Administration; 2012.

32. Kim M. Study on the management trend of domestic and foreign countries toward food irradiation. Seoul, Korea: Korea Food \& Drug Administration; 2004

33. Kim H, Kim M. Consumer attitudes towards irradiated foods. J Korean Home Econ Assoc. 2003;41:119-130.

34. Park SH, Seo HY. Improvement of public understanding on irradiation medical supplies. Gwacheon, Korea: Ministry of Science and Technology; 2005.

35. Byun MW, Lee JW. Application of irradiation technology for food safety and security. Food Sci Ind. 2003;36:25-41.

36. Choi J, Nam K, Li X, Kim H, Cho H, Hwang K, et al. Changes of surface color formation and constituents of white ginseng prepared with peeling by using barker. Korean J Crop Sci. 2008;53: 
369-375.

37. Kim MJ, Li X, Han JS, Lee SE, Choi JE. Effect of blue and red LED irradiation on growth characteristics and saponin contents in Panax ginseng CA Meyer. Korean J Med Crop Sci. 2009;17:187191.

38. Park CG, Jeon BS, Yang JW. The chemical components of Korean ginseng. Food Ind Nutr. 2003;8:10-23.

39. Kang IJ. Safety evaluations of irradiated foods. J Korean Soc Food Preserv. 2003;10:252-260.

40. Kim H, Un J. Food irradiation 1. J Korean Vet Med Assoc. 2001;37: 447-456.

41. Gwon JH. Irradiated food and consumers' acceptability. Food Ind 1995;131:25-43.

42. Park T. Irradiated food and media promotion strategies. Food Preserv Process Ind. 2010;9:70-74.

43. Langford I, Claire Morris C, O'Riordan T. Public reactions to risk: social structures, images of science and the role of trust. In: Ben- nett $\mathrm{P}$, Calman $\mathrm{K}$, editors. Risk communication and public health. New York, NY: Oxford University Press; 1999. p. 33-50.

44. Shon KY. Development of decision-making model incorporating the public risk perception to nuclear power in Korea [master's thesis]. Seoul, Korea; Seoul National University; 2000.

45. Roberts DA. Scientific literacy/science literacy. In: Abell SK, Lederman NG, editors. Handbook of research on science education. Mahwah, NJ: Lawrence Erlbaum Associates; 2007. p. 729-780.

46. Sadler TD. Informal reasoning regarding socioscientific issues: a critical review of research. J Res Sci Teach. 2004;41:513-536.

47. Zeidler DL, The role of moral reasoning on socioscientific issues and discourse in science education. Amsterdam, The Netherlands: Kluwer Academic Press; 2003.

48. Zeidler DL, Sadler TD, Simmons ML, Howes EV. Beyond STS: a research-based framework for socioscientific issues education. Sci Educ. 2005;89:357-377. 